\title{
The decline of deference and the left: An egalitarian moment for localism
}

\section{Florence Sutcliffe-Braithwaite}

Commentators on all sides of the political spectrum now claim that we live in a less deferential society. John McTernan wrote last year that 'it is a fact of life. The decline of deference, the rise of cynicism, call it what you will - you may regret it, but the world has changed'. ${ }^{1}$ In 2007, the Observer reported that Tony Blair had presided over a 'collapse' in deference - to experts and to government information - and concluded that although Iraq played a major part, it was only one factor in a longer trend. ${ }^{2}$ The techno-futurist Ukip MP Douglas Carswell, in the aftermath of the EU referendum, put it down to the rise of technology. ${ }^{3}$

The decline of deference is closely related to the rise of 'individualism', and this might lead us to see it as synonymous with the rise of selfishness, greed and a rejection of collectivism. This, however, is far from satisfactory. Thatcher is often presented as the chief architect, or prime beneficiary (or both), of the rise of individualism. On the day after her death, the Guardian printed Hugo Young's judgement on her. One of the three changes for the worse that Young associated with the Thatcher years was a change in the 'temper of Britain and the British', as Thatcherism 'fathered a mood of tolerated harshness. Materialistic individualism was blessed as a virtue, the driver of national success' ${ }^{4}$

Individualism shouldn't be simply linked to Thatcherism, though, and nor should it be equated with selfishness. Individualism - in the sense in which it is closely related to the decline of deference - is not simply a 'me first' attitude. Rather, it is an insistence on the individual's right to respect, to make their own choices, to define their own goals. No society is ever entirely individualistic: we are all shaped by social norms. However, across the postwar period, Britain has become less bound by tradition and convention; people are more keen to make up their own minds, less willing to accede to the rightness of hierarchies and snobbishness.

As early as the 1970s, Ronald Inglehart began to theorise the rise of 'post-materialist' values and ethical concerns which, he argued, were coming to supplement the old, materialist, class concerns of politics as ordinary people gained greater prosperity and security. ${ }^{5}$ Building on Inglehart's analysis,

\footnotetext{
${ }^{1}$ McTernan J (2015) 'Will MPs never learn that they aren't trusted?', Telegraph, 23 December 2015

${ }^{2}$ Watt N (2007) 'The nation loses trust in its leaders', Observer, 10 June 2007.

${ }^{3}$ Carswell D (2016) 'Farage's 'breaking point' posters were indefensible - but I'm glad we voted leave', Guardian, 27 June 2016, https://www.theguardian.com/commentisfree/2016/jun/27/britain-eu-vote-leave-ukip. ${ }^{4}$ Young H (2013) 'She has left a dark legacy that has still not disappeared', Guardian, 9 April 2013.

${ }^{5}$ Inglehart R (1977) The Silent Revolution: Changing Values and Political Styles among Western Publics, Princeton University Press.
} 
later social scientists like Anthony Giddens posited that in the late 20th century, 'disembedding mechanisms' prised social relations free from tradition, undercutting traditional hierarchies, habits and customs. He described this 'new individualism' as a whole new orientation to life based on personality and individual choice; it was not selfish but often profoundly ethical. ${ }^{6}$

The decline of deference and rise of individualism was underway well before Thatcher. Even in the late 1960s, you could find a shipbuilder on Tyneside reflecting,

'I believe in thinking for myself about politics. When I was young in Walker [a suburb of Newcastle], it was all Labour, you had to be Labour, everybody was Labour. Now I believe in thinking for myself, and next time I'm going to vote Conservative'. ${ }^{7}$

Twenty-five years later, Giles Radice's Southern Discomfort research found interviewees - average voters, in marginal seats - voicing similar sentiments. There was, Radice says,

'stronger support for more individualistic values such as opportunities and choice, which were usually associated with the Conservatives. "Freedom for the individual" was too abstract to have much resonance, though most agreed it was a Conservative idea. One interviewee remarked "It is obviously Conservative. The Labour party would put you in a group".'

We should not make the mistake of assuming, though, that the decline of deference inevitably favours the right. In fact, it is a cultural change larger than either left or right. In the 1980s, Thatcher succeeded in convincing many that it was her populist and anti-establishment rhetoric, and her vision of a small state and free market, that represented the greatest liberty for the individual. However, it is also a shift that holds out potential for the left.

The decline of deference also involved a refusal to accept the old, class-bound social hierarchies. Numerous statements attesting to this can be found in an oral history project from the mid-1980s. Pamela Pittuck (born in 1930, a secretary and bookkeeper in south east England), for example, said,

'I don't think you can tell social classes in this day and age. I mean, years ago, there was. You'd look at somebody and say oh yes, they're working class because they've got - but they're not anymore. People act and dress exactly as they want to.'

\footnotetext{
${ }^{6}$ Giddens A (1991) Modernity and Self-Identity: Self and Society in the Late Modern Age, Polity Press: 1; and (1998) The Third Way: The Renewal of Social Democracy, Polity Press: $35 f f$.

${ }^{7}$ Brown R et al (1968-1969) 'Observation notes on blacksmiths (shop and ship)', part of the 'Orientation to Work and Industrial Behaviour of Shipbuilding Workers on Tyneside' project, Modern Records Centre, University of Warwick: MSS.371/Ship/Box 1/file 3.

${ }^{8}$ Radice G (1992) Southern Discomfort, Fabian Society: 9.
} 
Pittuck went on, 'I can mix with any class now which years ago I couldn't. I used to feel inferior'. ${ }^{9}$ Similarly, Rosemary Vincent (born 1945, working in personnel for a college of further education, planning to do a diploma in management studies, living in north west England) explained in her interview, 'I was brought up to believe I was working class and I always would be, and anybody who has a title or a good job, was somebody that was far superior than I was'. However, she continued, 'as you do grow up and you come to meet these people, they're all people, and I think too much emphasis is placed on somebody being superior to somebody else' ${ }^{10}$ The decline of deference often underpinned an assertion of an egalitarian view of society, and the belief that no one should style themselves as 'superior'. From this angle it must be something that the left welcomes.

The decline of deference and rise of more individualistic orientations have driven big and important shifts in politics across many axes, though they are by no means solely responsible for them. From the late 1960s, there was a revival in grassroots trade union militancy as workers rejected the authority of both bosses and trade union hierarchies. 1956 saw the foundation of the 'New Left' and of the Campaign for Nuclear Disarmament, the first of the 'new social movements' built around issues like peace, gender, race, sexuality and environmentalism, which exploded from the late-1960s onwards. The 1960s also saw the beginnings of class de-alignment in voting habits: by the end of the 1970s, political scientists were writing books with titles like Decade of dealignment and Voters Begin to Choose: From Closed-Class to Open Elections in Britain. ${ }^{11}$ Anti-political sentiments rose across the postwar period, and there was a general trend of decline in turnout at elections. ${ }^{12}$ The late 20th century also saw the beginnings of the rise of small populist and radical parties like Ukip. ${ }^{13}$

In recent years the process of class de-alignment in voting, and the growth of anti-political sentiments and mistrust of elites, have all become more pronounced. Turnout in general elections between 2001 and 2015 was between just 59 and 66 per cent. The rise of both the Greens and Ukip has been dramatic. Populist, anti-establishment messages have not merely flourished in the shape of small parties, but in Jeremy Corbyn's campaign for the Labour leadership.

In part, though not in their entirety, these developments can be traced back to the decline of deference. It very clearly poses serious challenges for left politics as we have known it. Yet the

\footnotetext{
9 'Interviewee 108, Pamela Pittuck', in Thompson P and Newby H (2005) 'Families, Social Mobility and Ageing, an Intergenerational Approach, 1900-1988', SN: 4938, data collection, UK Data Service.

10 'Interviewee 147, Rosemary Vincent', in Thompson and Newby 2005.

${ }^{11}$ Särlvik B and Crewe I (1983) Decade of dealignment: The Conservative victory of 1979 and electoral trends in the 1970s, Cambridge University Press; Rose R and McAllister I (1986) Voters Begin to Choose: From ClosedClass to Open Elections in Britain, SAGE Publications.

12 Stoker G, Moss J, Clarke N and Jennings W (2016) 'Anti-Politics and the Left', Renewal 24(2).

${ }^{13}$ Ford R and Goodwin M (2013) Revolt on the Right: Explaining Support for the Radical Right in Britain, Routledge.
} 
decline of deference must be seen as a positive development. It means a society in which people are not willing to accept being treated as inferior; in which people insist that all social groups are worth just as much as others; in which people cast a sceptical eye on elites and hierarchies, and demand power and control in their own lives. So what should or could the left do? One answer lies in policies and political processes that increase people's liberty, autonomy and control over their lives: participatory democracy, devolution and localism, democratising our economic structures and the social state.

In the 1950s and 1960s, just as commentators were beginning to note the decline of deference, the rise of new social movements and class de-alignment in voting, there was a sudden upsurge of interest in localism, the devolution of power, and the democratisation of policymaking. The New Left wanted to promulgate the ideal of 'active citizenship'; radical Young Liberals were interested in community organising from the ground up; there were even new forms of participatory politics advocated on the right by Diana Spearman and Enoch Powell. ${ }^{14}$ There was a great deal of enthusiasm for the democratisation of industry; the radical Bennite Institute for Workers' Control (IWC) was established in 1968 to advocate for a strong vision of worker control. It is no coincidence that these ideas gained traction at this moment. There are, therefore, long precedents for the left looking to radical programmes of democratisation and localisation of control of the economy, politics and the welfare state.

New Labour was anti-statist in the sense that its architects rejected corporatism and centralised planning in favour of a new version of Keynesianism and supply-side economics. ${ }^{15}$ But it was also a centralised and managerialist project, driven by a small elite. The 'New Labour that wasn't' once promised constitutional and political reform to bring power and policymaking closer to people, ${ }^{16}$ but in this area it failed to fully follow through. It was this insight that led Ed Miliband to emphasise that the future for Labour had to involve spreading power more widely, as when he argued in 2014,

\section{I care about inequality of income and opportunity. But I care about something else as well. Inequality of power. Everyone - not just those at the top-should have the chance to shape their own lives. ${ }^{17}$}

\footnotetext{
${ }^{14}$ Foote G (2006) The Republican Transformation of Modern British Politics, Palgrave Macmillan: 89-92.

${ }^{15}$ Tomlinson J (2007) 'Tale of a Death Exaggerated: How Keynesian Policies Survived the 1970s', Contemporary British History 21: 429-448.

${ }^{16}$ White S and O'Neill M (2013) 'The New Labour That Wasn't: Lessons for Miliband', Fabian Review 125(1).

${ }^{17}$ Goes E (2016) The Labour Party under Ed Miliband: Trying but Failing to Renew Social Democracy, Manchester University Press: 121 . See also chapter 5, for full discussion of Miliband's agenda.
} 
This agenda is currently garnering more attention than ever on the left, and it might provide a way to harness the left's traditional focus on distributive justice to an agenda that can speak to the new concerns and hopes stimulated by the decline in deference in our society. ${ }^{18}$

Gordon Brown, Ed Balls and others on the left have been sceptical of this agenda - and their reservations deserve serious consideration. The achievements of New Labour were driven by the central state taking decisions, redistributing money and instigating new policies: tax credits, Sure Start centres, investment in education and health, the minimum wage. Brown's first two budgets alone effected the largest redistribution from rich to poor in decades..$^{19}$ By 2007, New Labour had made Britain a fairer and more equal society than it was in 1997 - a huge difference from what we would have seen under a further 10 years of Conservative government. ${ }^{20} \mathrm{~A}$ localist agenda cannot lead us to neglect the importance of the national level. This is all the more important given that British local government does not exist as a matter of constitutional right, but as a set of privileges bestowed by a distant crown-in-parliament. Our centralised constitutional arrangements mean that victory in national politics is vital to give us a left government that can demonstrate a commitment to localising and devolving power, as well as pulling the central levers of policy.

However, this agenda - localism, devolution, participatory democracy and the democratisation of the economy and policymaking - now deserves renewed attention as a way to speak to people's demands for greater control within their lives (it's no coincidence that the Leave campaign's most favoured slogan in the EU campaign was 'take back control'). It also offers the possibility of breaking out of some of the stale binaries of entrenched policy positions within Labour. Many policies have a symbolic, virtue-signalling effect that far surpasses their actual radicalism or importance to any potential Labour programme of government. An agenda of grassroots empowerment through localism, participation and democratisation of the structures of state and economy would have the power to bring together (superficially) unlikely coalitions within Labour. As Ben Jackson wrote last year in his final editorial for Renewal, there might be more areas of consensus within Labour than there appear to be, if only we can seek them out. ${ }^{21}$

\footnotetext{
${ }^{18}$ See Chwalisz C (2016) The Populist Signal: Why Politics and Democracy Need to Change, Policy Network; Kelly M, McKinley S and Duncan V (2016) 'Community wealth building: America's emerging asset based approach to city economic development', Renewal 24(2): 51-68; Brown M and O'Neill M (2016) 'The Road to Socialism is the A59: The Preston Model', Renewal 24(2): 69-78; Studdert J (2016) 'Place-based health: Why local accountability would lead to better quality and outcomes', Renewal 24(2); Balata F (2016) 'Shaping a new deal for coastal communities', Renewal 24.2; and Ferretti T (2015) 'Mondragon in Five Points', Renewal 23(4): 37-54.

${ }^{19}$ Rawnsley A (2001) Servants of the People: The inside Story of New Labour, Penguin: 157.

${ }^{20}$ Stewart K (2007) 'Equality and Social Justice', in Seldon A (ed) Blair's Britain, 1997-2007, Cambridge University Press: 408-435 (at 434-435).

${ }^{21}$ Jackson B (2015) 'Labour's ideology: towards common ground', Renewal 23(4).
} 
Joe Guinan recently argued in Renewal that we should 'bring back the Institute for Workers' Control'. ${ }^{22}$ Liz Kendall also argued for greater worker power in the firm during her Labour leadership run last year, drawing on ideas associated with 'Rhineland capitalism': she argued that workers' interest in their company's performance may well be more informed and more long-term than that of many shareholders, and that their input into productivity, training, working arrangements and innovation decisions might be of economic value to the company as well as empowering workers. ${ }^{23}$ Shadow chancellor John McDonnell has developed this agenda, building on the work of radical economic thinkers like Mariana Mazzucato to suggest that we could build a more resilient economy with more worker control and more local control. ${ }^{24}$

A decentralisation strategy will require a connection between the party, state and civil society at multiple levels - between the parliamentary Labour party, local government, trade unions and others. This demands a pluralist, stakeholder approach to party management, rather than the majoritarian, centralised approach favoured all too often by party leaderships that feel beleaguered (Tony Blair and Jeremy Corbyn to name just two). ${ }^{25}$ There is, however, a consensus and a strong policy position for Labour in this agenda, if the party can grasp it.

Florence Sutcliffe-Braithwaite is a lecturer in 20th century British history at University College London, and co-editor of Renewal: A Journal of Social Democracy.

\footnotetext{
22 Guinan J (2015) 'Bring Back the Institute for Workers' Control', Renewal, 23(4): 11-36.

${ }^{23}$ Hildyard L (2015) 'Liz Kendall shows her red side', blog, Left Foot Forward, 1 July 2015. http://leftfootforward. org/2015/07/liz-kendall-shows-her-red-side/.

${ }^{24}$ McDonnell J (2016) 'Building an Entrepreneurial State at a Local Level', speech delivered at TAS Partnership Limited, Preston, 20 April 2016. http://press.labour.org.uk/post/143115086454/building-anentrepreneurialstateat-a-local-level. ${ }^{25}$ Shaw E (2016 forthcoming) 'Review of The Blair Supremacy: A study in the politics of Labour's party management, by Lewis Minkin', Renewal 24(3).
} 